\title{
Legal Protection for Auction Winners of Liability against Transition of Land Rights Certificates
}

\author{
Marliyanti Praja Kusuma*) and Sri Kusriyah ${ }^{* *}$ \\ $\left.{ }^{*}\right)$ Faculty of Law, Universitas Islam Sultan Agung (UNISSULA) Semarang, E-mail: \\ marliyanti89@gmail.com
}
$\left.{ }^{* *}\right)$ Faculty of Law, Universitas Islam Sultan Agung (UNISSULA) Semarang, E-mail: kusriyah@unissula.ac.id

\begin{abstract}
In this journal the author has two objectives in this research, first, To find out and analyze the legal protection of the auction winner of mortgage rights in the transfer of land rights certificates and To find out and analyze the legal position of the transfer of land rights certificates for the auction winners in the construction of legal certainty. The approach method in this research is normative juridical where this research provides a detailed, systematic and comprehensive description in which the author examines and studies the norms contained in the legislation. The research specification is a descriptive analysis that is limited to efforts to reveal a problem or situation or event as it is, so that it is merely revealing facts. The data required includes primary data, secondary data, and tertiary data. Taken by data collection method, data analysis method using qualitative approach, namely understanding the data through collecting, filtering, analyzing and making conclusions on the data obtained throughout the research systematically. Based on the research, it can be concluded that legal protection for legitimate auction winners is still difficult in practice. The existence of disputes and lawsuits from land owners does not provide legal certainty of the status of the auction object being sold where buyers who have good intentions participate in the auction process and have fulfilled their obligations but sometimes cannot immediately enjoy the goods purchased. Although the acquisition of the object of the auction in the form of a Mortgage object is in accordance with the procedural and legally valid, however, the administrative requirements at the Land Office cannot be carried out due to the status quo.
\end{abstract}

Keywords: Auction; Land; Legal; Protection; Rights; Transfer; Winner. 


\section{Introduction}

Auction or sale in public is a sale of goods carried out in front of the public where the price of goods offered to buyers is increasing every time. ${ }^{1}$ In addition, Article 1 of the Vendu Reglement (VR) which is the main rule of auction brought by the Netherlands states: "General sales (auctions) are sales of goods made to the public by offering an increased price or by entering the price in a closed envelope, or to persons who have been invited or previously notified of the auction or sale, or are permitted to participate, and are given the opportunity to bid prices, agree on the prices offered or include prices in closed envelopes".

The definition of auction can also be found in the provisions of Article 1 point 1 of the Regulation of the Minister of Finance Number 213/PMK.06/2020 concerning Auction Implementation Guidelines (hereinafter referred to as PMK concerning Auction Implementation Guidelines), which states: Auction is the sale of goods open to the public at an offer price in writing and/or orally increases or decreases to reach the highest price, which is preceded by the Announcement of the Auction. ${ }^{2}$

The auction buyer or the winner of the auction is the person or legal entity/business entity that submits the highest bid and is ratified as the winner of the auction by the Auction Officer. ${ }^{3}$ Any individual or legal entity or business entity may become a bidder. However, there are legal subjects who are excluded as bidders, namely those who are directly related to the auction process and are prohibited by laws and regulations from being bidders.

Auctions that have been carried out in accordance with applicable regulations cannot be cancelled. Auction cancellations can only be made prior to the auction. During the auction implementation stage, the limit price is determined by the seller and submitted to the auction official before the auction begins. The bidding method is determined by the Head of the Auction Office by taking into account the suggestions from the seller. The bidding method must be announced in front of potential buyers (media, leaflets, internet). Bids submitted cannot be changed or canceled by bidders. In the implementation of the auction, initially, the announcement of the bidding of the goods that are used as the object of the auction is made openly to the prospective bidders at the same time. On the day that has been determined the auction is carried out by the bidders.

\footnotetext{
${ }^{1}$ S, Salim H. (2011). Perkembangan Hukum Jaminan di Indonesia. Jakarta: Rajawali Pers. p. 239

${ }^{2}$ Minister of Finance Regulation Number 213/PMK.06/2020 concerning Auction Implementation Guidelines.

${ }^{3}$ F.X. Ngadijarno, Nunung Eko Laksito, and Isti Indri Listiani, (2009), Lelang: Teori dan Praktik, Jakarta: Badan Pendidikan dan Pelatihan Keuangan Depatyemen Keuangan, p. 94.
} 
Basically, the legal relationship between the parties in the auction is buying and selling. According to Article 1457 of the Civil Code ${ }^{4}$, buying and selling is an agreement between the seller and the buyer where the seller binds himself to surrender his ownership rights to an item to the buyer, and the buyer binds himself to pay for the goods. ${ }^{5}$ Meanwhile, the sale and purchase of land is a legal act of transferring land rights with payment of the price at the same time in cash $^{6}$, then by handing over the land to the buyer and paying the price to the seller at the time the sale and purchase is made, the act of buying and selling is completed. In the sense that the buyer has become the holder of his new rights by being preceded by the name transfer of the land certificate. Thus, the winner of the auction has fully become the owner and has the right to control and enjoy the goods, and since then the buyer has been able to request physical delivery of the goods or demand the submission of the deeds related to the goods he purchased or to have his name reversed. The auction winner who has obtained the minutes of the auction has the right to register his land rights with the National Land Agency (BPN) in order to change the name from the old owner to the new owner. ${ }^{7}$

Legally, the auction winner has legal certainty over the auction items he bought with the minutes of the auction. Minutes of auction are minutes of auction which are the basis for authentication of auction sales. Minutes of auction record all events that occur in auction sales. ${ }^{8}$ The auction winner who has obtained the minutes of the auction has the right to register his land rights with the National Land Agency for the purpose of changing the name from the old owner to the new owner. In other words, the ownership rights are fully transferred to the auction winner if after the auction winner has fulfilled all the requirements of the auction.

Problems arise when the legislation contained in Article 45 paragraph (1) letter e Government Regulation Number 24 of 1997 concerning Land Registration states

\footnotetext{
${ }^{4}$ A Chuasanga, Ong Argo Victoria. (2019). Legal Principles Under Criminal Law in Indonesia and Thailand, Jurnal Daulat Hukum, Vol 2, No 1 (2019) http://jurnal.unissula.ac.id/index.php/RH/article/view/4218 see also Deen, Thaufiq., Ong Argo Victoria \& Sumain. (2018). Public Notary Services In Malaysia. JURNAL AKTA: Vol. 5, No. 4, 10171026. Retrieved from http://jurnal.unissula.ac.id/index.php/akta/article/view/4135

${ }^{5}$ Khairandy Ridwan. 2017. Pokok-pokok Hukum Dagang Indonesia. Yogyakarta. UII Press, p. 467

${ }^{6}$ Budi Harsono, (1983), Penggunaan dan Penerapan Asas-asas Hukum Adat pada Hak Milik atas Tanah, paper disampaikan pada Simposium Hak Milik Atas Tanah Menurut UUPA, Bandung ${ }^{7}$ Ibid.

${ }^{8}$ Harahap, M.Yahya. (1994). Ruang Lingkup Permasalahan Eksekusi Bidang Perdata. Jakarta: Gramedia, p. 187.
} 
that the Head of the Land Office refuses to register transfers or assign rights, if the land in question is the object of dispute in the Court. ${ }^{9}$

Considering the relatively still land condition, there are still many who have not changed the name of the transfer of ownership rights to land obtained from the auction results. Blocking when there is a land dispute is an action that should not be ignored because it is important to fortify so that the object of the disputed land cannot be transferred to any party. It also avoids prolonged legal disputes by alternating parties to the dispute. The status of the land requested for blockage, if it is approved by the Head of the Land Office or the competent authority, no legal action can be taken, cannot be transferred to other parties, placed as collateral for debts and so on. If that happens, the legal action on it is null and void ${ }^{10}$.

\section{Research Methods}

The research method used in writing this thesis is using a normative juridical research method, meaning that this method is carried out by examining library materials or secondary data. The juridical approach refers to applicable laws and regulations, while the normative approach is carried out by examining library materials or secondary data on legal principles and case studies or commonly referred to as library law research. The research specification in this writing is descriptive analytical which is limited to efforts to reveal a problem or situation or event as it is, so that it is merely revealing facts. Research on theory and practice is used with the aim of obtaining an overview of the application of a theory in society and to describe existing realities and describe the object that is the subject of the problem. In terms of data collection techniques using document studies with the aim of obtaining information in the form of formal provisions and existing official texts and interviews by asking questions directly to the interviewees, especially to people who are authorized, know and are related to land registration because auction.

The data analysis method used itself is qualitative analysis, namely data obtained through field research and library research which are then compiled systematically and then analyzed qualitatively to achieve clarity on the problems to be discussed, then the data will be analyzed interpretively using theory and

\footnotetext{
${ }^{9}$ Sutedi, Adrian. (2010). Hukum Hak Tanggungan. Jakarta: Sinar Grafika, p. 32.

10 Ong Argo Victoria, Ade Riusma Ariyana, Devina Arifani. (2020). Code of Ethics and Position of Notary in Indonesia. Sultan Agung Notary Law Review 2 (4), 397-407, http://lppmunissula.com/jurnal.unissula.ac.id/index.php/SANLaR/article/view/13536 see also Yaya Kareng, Ong Argo Victoria, R. Juli Moertiyono. (2019). How Notary's Service in Thailand. Sultan Agung Notary Law Review, 11 46-56,
} http://jurnal.unissula.ac.id/index.php/SANLaR/article/view/4435 
positive law that has been poured then deductively drawn conclusions to answer the existing problems.

\section{Results and Discussion}

3.1. Legal protection for the winner of the mortgage auction in the transfer of certificates of land rights Based on Government Regulation Number 24 of 1997 concerning Land Registration

The winner of the auction is based on the Regulation of the Minister of Finance No213/PMK.06/2020 concerning instructions for auction implementation, is the buyer who submits the highest bid and is ratified as the winner of the auction by the Auction Officer.

The statement of a person as the winner of the auction has not been effective as the owner of the goods. There are times when someone's statement as the winner of a new auction is a process towards the transfer of ownership rights. Ownership rights are fully transferred if after the auction winner fulfills the requirements of the auction, namely the payment of the price and the auction official authorizes the auction winner by being given the Minutes of Auction.

Registration of Land Rights In order to ensure legal certainty of land rights, on the one hand the BAL requires the government to hold land registrations throughout the territory of the Republic of Indonesia, and on the other hand the $B A L$ requires the holders of the rights concerned to register their land rights. In relation to the income of K. Wanjik Saleh who stated that: "Article 19 of the LoGA is directed at the Government to carry out land registration throughout the territory of the Republic of Indonesia, it is the government's obligation as the highest authority over land, rights to cultivate, right to use buildings, any transfers, write-offs and encumbrance with other rights that must be registered is an obligation for those who have other rights, must be obtained, is an obligation for those who have these rights, ${ }^{11}$

Article 19 of Act No. 5 of 1960 concerning Basic Agrarian Basic Regulations (abbreviated UUPA) asserts that land registration is intended to provide legal certainty, legal certainty here in the sense that there is certainty of land rights. ${ }^{12}$

Article 41 of Government Regulation No. 24 of 1997 confirms that the registration of the transfer of land rights through auction can only be registered if it is proven by the minutes of the auction made by the auction official, both in the context of an execution auction and a non-execution auction. The excerpt of

\footnotetext{
${ }^{11}$ Saleh K. Wanjik.2000. Hak Anda Atas Tanah. Jakarta. Ghalia Indonesia, p. 61

12 Directorate General of State Assets, www.dkjn.depkeu.go.id
} 
the minutes of the auction is already proof of the transfer of land rights, like a deed of sale and purchase in a legal act of buying and selling land. However, as with other legal actions, the auction winner must register the transfer of his rights to the land office first in order to obtain legal certainty over the transfer of land rights obtained from the auction process.

After the auction participant has been declared the winner of the auction and has received the minutes of the auction as the new legal owner, the winner of the auction can immediately register the auction he won. In order to obtain legal certainty over the land, the execution auction process, according to Article 41 paragraph (4) letter a number 1 of the Government Regulation concerning land registration confirms that the execution auction can still be carried out even though the original certificate of the right is not obtained by the auction official from the right holder.

Credit distribution provided by banking institutions to debtors is accompanied by the binding of the debtor's guarantee with the "Deed of Granting Liability Rights (APHT)". APHT basically provides legal certainty and authority to mortgage holders to make public sales of collateral if the debtor defaults (parate execution) as part of the credit settlement process carried out by the bank/creditor.

On the implementation of the auction of Article 6 UUHT which is sold and has been determined by the winner of the auction, a minutes of auction will be made by the auction official which functions as an authentic deed of the transfer of rights to the land from the old owner (debtor) to the winner of the auction. Furthermore, based on the minutes of the auction, the winner of the auction can arrange for a name transfer to the office of the National Land Agency.

In practice, there are dynamics that may occur in the creditor's efforts to sell collateral through auction, one of which is an attempt to file a lawsuit or rebuttal to the court from the debtor addressed to the creditor as the seller, KPKNL as an intermediary for the auction, and the winner of the auction. Therefore, there are still people who are not interested in participating in the auction because the process is quite vulnerable to legal remedies such as lawsuits. This should be a concern for the relevant parties to conduct education so that the public knows the process that needs to be done in order to get legal protection.

Many factors can lead to lawsuits or objections, one of which occurs because the debtor may not want to hand over the object that has been auctioned off to the auction winner voluntarily. However, the APHT basically has an agreement regarding the emptying of the mortgage object at the time of execution of the mortgage in accordance with the provisions of Article 11 paragraph (2) letter K of the UUHT, so that there is no longer any reason for the debtor to circumvent and 
refuse to vacate. For the actions of the debtor, the winner of the auction may submit a request for Execution of Clearing to the court.

Prior to submitting a request for execution of voiding to the court, the auction winner submits an application for Grosse Minutes of Auction which is the original copy of Minutes of Auction with the head "For Justice Based on the Supreme Lord" to the KPKNL. Grosse Minutes of Auction has executive power which has the same force as a decision which has permanent legal force. After obtaining the Grosse Minutes of Auction, the winner of the auction can submit a request for voiding to the Head of the local District Court without having to go through a lawsuit. This is in accordance with the provisions of Article 200 paragraph (11) of HIR and Circular Letter of the Supreme Court (SEMA) Number 4 of 2014 concerning the Enforcement of The formulation of the results of the 2013 Supreme Court Chamber Plenary Meeting as a Guide to the Implementation of Duties for the Court which states "With respect to the auction of mortgage rights by creditors themselves through the auction office, if the auctioneer does not want to vacate the object of the auction, the auction execution can be directly submitted to the Head of the District Court without going through a lawsuit".${ }^{13}$

Furthermore, after the application for execution of voiding is submitted to the Chairman of the District Court, the Chairman of the District Court issues a decision for aanmaning which contains an order to the bailiff to summon the Respondent for execution to be present at the aanmaning session which will be attended by the Chairman, Registrar and Execution Respondent. Later in the trial, the Head of the District Court will warn the Executing Respondent to vacate the object of execution. The Chairperson of the Court then issues an execution order to the Registrar/Jurista to be then notified to the parties in the execution and the officials involved in carrying out the execution.

Meanwhile, if prior to the execution of the vassal, the Respondent for the execution took action against the court so that the execution of the execution was suspended, then the person authorized to suspend or continue the execution is the Head of the District Court. Therefore, the importance of an adequate understanding of the existing statutory regulations will in principle provide legal protection for the auction winner to control the collateral goods purchased through auction and the resistance submitted by the Execution Respondent.

The land office of Sukoharjo Regency as the recording agency, of course, in this case, is waiting for legal certainty, namely if the lawsuit filed by the debtor has not obtained permanent legal force based on Government Regulation Number

\footnotetext{
${ }^{13}$ Results of an interview with Mr. Yudho Gintoro, Executive Staff of the Conflict and Case Survey Section of the Sukoharjo BPN, on Monday 9 November 2021
} 
24 of 1997, especially article 45 letter e, the Land Office cannot carry out the transition process rights to the auction winner because the land is still the status quo in court. Although the acquisition of the object of the auction in the form of a Mortgage object is in accordance with the procedural and legally valid, however, the administrative requirements at the Land Office cannot be carried out due to the status quo.

3.2. The legal position of the transfer of certificates of land rights for the winner of the auction of Mortgage Rights Based on Government Regulation Number 24 of 1997 concerning Land Registration in the construction of legal certainty

Article 41 paragraph (1) Government Regulation no. 24/1997 concerning land registration, it is explained that the transfer of land rights through the transfer of rights by auction can only be registered if it is proven by an excerpt from the minutes of the auction made by the auction official. The minutes of the auction have the same position as the deed of sale and purchase made by the Land Deed Making Officer (PPAT) which is usually used as a basis for registering the exercise of land rights at the Land Office.

Based on Article 41 of Government Regulation Number 24 of 1997 concerning Transfer of Rights by Auction as follows:

(1) The transfer of rights through the transfer of rights by auction can only be registered if it is proven by an excerpt from the minutes of auction made by the Auction Officer.

(2) At the latest 7 (seven) working days before a plot of land or an apartment unit is auctioned, either in the context of an execution auction or a non-execution auction, the Head of the Auction Office is obliged to request information as referred to in Article 34 to the Land Office regarding the plot of land or apartment unit to be auctioned.

(3) The Head of the Land Office issues the information as referred to in paragraph (2) no later than 5 (five) working days after receiving the request from the Head of the Auction Office.

(4) The Head of the Auction Office refuses to conduct the auction, if:

a. regarding land that has been registered or ownership rights to the apartment unit:

1) to him the original certificate of the right in question is not handed over, except in the case of an execution auction which can still be carried out even 
though the original certificate of the right is not obtained by the Auction Officer from the holder of the right; or

2) the certificate submitted does not match the registers at the Land Office; or

b. regarding parcels of land that have not been registered, it is not submitted to him:

1) proof of rights as referred to in Article 24 paragraph (1), or a certificate from the Village Head stating that the person concerned controls the parcel of land as referred to in Article 24 paragraph (2); and

2) a certificate stating that the land parcel in question has not been certified from the Land Office, or for land located in an area far from the Land Office's domicile, from the right holder in question, supported by the Village Head; or

c. there is an order from the District Court not to carry out the auction in connection with the dispute regarding the land in question.

(5) For registration of transfer of rights obtained through auction, it is submitted to the Head of the Land Office:

a. a quote from the relevant auction minutes;

b. 1) certificate of ownership of the apartment unit or land rights that are being auctioned off if the land parcel in question is already registered; or

2 ) in the event that the certificate is not submitted to the buyer of the execution auction, a statement letter from the Head of the Auction Office regarding the reasons for not submitting the certificate; or

3 ) if the land parcel in question has not been registered, the documents as referred to in paragraph (4) letter b of this Article;

c. proof of identity of the auction buyer;

d. proof of payment of the purchase price.

\section{Conclusion}

Legal protection for legitimate auction winners is still difficult in practice. The existence of disputes and lawsuits from land owners does not provide legal certainty of the status of the auction object being sold where buyers who have good intentions participate in the auction process and have fulfilled their 
obligations but sometimes cannot immediately enjoy the goods purchased. The responsibility for the loss suffered by the auction buyer is the buyer's responsibility as regulated in Article 16 of the Regulation of the Minister of Finance Number 213/PMK.06/2020 concerning Auction Implementation Guidelines. The land office as the recording agency, of course, in this case, is waiting for legal certainty, namely if the lawsuit filed by the debtor has not obtained permanent legal force based on Government Regulation Number 24 of 1997, especially article 45 letter e, the Land Office cannot carry out the process of transferring rights to the winner of the auction because the land is still the status quo in court. Although the acquisition of the object of the auction in the form of a Mortgage object is in accordance with the procedural and legally valid, however, the administrative requirements at the Land Office cannot be carried out due to the status quo.

\section{References}

Journals:

[1] Catur Budi Dianawati, dan Amin Purnawan.(2017). "Kajian Hukum Jaminan Hak Tanggungan yang Dilelang Tanpa Proses Permohonan Lelang Eksekusi Ke Ketua Pengadilan Negeri", Jurnal Akta. Nomor 2.

[2] A Chuasanga, Ong Argo Victoria. (2019). Legal Principles Under Criminal Law in Indonesia and Thailand, Jurnal Daulat Hukum, Vol 2, No 1 (2019) http://jurnal.unissula.ac.id/index.php/RH/article/view/4218

[3] Deen, Thaufiq., Ong Argo Victoria \& Sumain. (2018). Public Notary Services In Malaysia. JURNAL AKTA: Vol. 5, No. 4, 1017-1026. Retrieved from http://jurnal.unissula.ac.id/index.php/akta/article/view/4135

[4] Ong Argo Victoria, Ade Riusma Ariyana, Devina Arifani. (2020). Code of Ethics and Position of Notary in Indonesia. Sultan Agung Notary Law $\begin{array}{llll}\text { Review } & 2 & (4), & \text { 397-407, }\end{array}$ unissula.com/jurnal.unissula.ac.id/index.php/SANLaR/article/view/13536

[5] Yaya Kareng, Ong Argo Victoria, R. Juli Moertiyono. (2019). How Notary's Service in Thailand. Sultan Agung Notary Law Review, 1 (1), 46-56, http://jurnal.unissula.ac.id/index.php/SANLaR/article/view/4435

Books:

[1] Harahap, M.Yahya. (1994). Ruang Lingkup Permasalahan Eksekusi Bidang Perdata. Jakarta: Gramedia.

[2] Khairandy Ridwan. 2017. Pokok-pokok Hukum Dagang Indonesia. Yogyakarta. UII Press. 
[3] S, Salim H. (2011). Perkembangan Hukum Jaminan di Indonesia. Jakarta: Rajawali Pers.

[4] Saleh K. Wanjik.2000. Hak Anda Atas Tanah. Jakarta. Ghalia Indonesia,

[5] Sutedi, Adrian.(2010).Hukum Hak Tanggungan. Jakarta: Sinar Grafika.

Regulation:

[1] Act No. 4 of 1996 concerning Mortgage Rights on Land and Objects Related to Land.

[2] Code of Civil law

[3] Minister of Finance Regulation Number 213/PMK.06/2020 concerning Auction Implementation Guidelines.

[4] Regulation of the State Minister of Agrarian Affairs/Head of the National Land Agency concerning Provisions for the Implementation of Government Regulation Number 24 of 1997 concerning Land Registration, Regulation Number 3 of 1997.

[5] Vendu Reglement (Rules for Auction) Ordonantie February 28, 1908, which was amended by Stb. 1940 Number 56 